\title{
A SURVEY ON EXTENT OF DOMESTIC WASTE OF VEGETABLES
}

\author{
BY
}

\section{RANASINGHE HETTIARACHCHIGE INDIKA DINUSHIE RANASINGHE}

2008

Thesis submitted to the University of Sri Jayewardenepura as partial fulfillment requirement for the award of the degree of Master of Science in Food Science and Technology. 
"The work described in this thesis was carried out by me under the supervision of Prof. A.Bamunuarachchi and Dr. K.K.D.S. Ranaweera and a report on this has not been submitted in whole or in part to any University or any other institution for another degree."

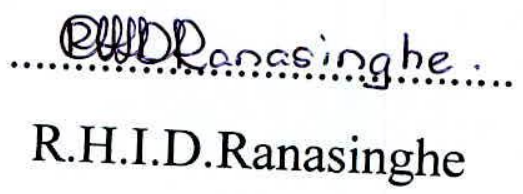


"We certify that the above statement made by the candidate is true and that this thesis is suitable for submission to the University for the purpose of evaluation".

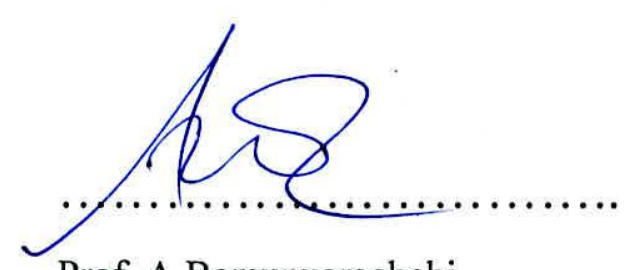

Prof. A.Bamunuarachchi,

Department of Food Science

\&Technology,

University of Sri Jayawardanapura,

Nugegoda.

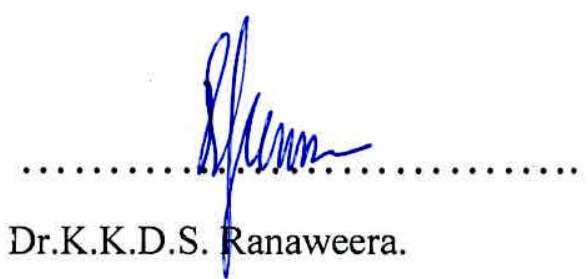

Coordinator/Food Science \& 'iecnology Programme,

Department of Food Science

\& Technology,

University of Sri Jayawardanapura,

Nugegoda. 


\section{CONTENTS}

Page

List of Tables

iv

List of Figures

v

Acknowledgement

vi

Abstract

vii-viii

CHAPTER 01

INTRODUCTION

1.1 Back ground to the study

1.2 Objectives of the study

CHAPTER 02

LITERATURE

2.1 Production of vegetables in Sri Lanka

2.2 Vegetable consumption in Sri Lanka

8-10

2.3 Nutritive values of vegetables

11-12

2.4 Post harvest losses of vegetables

12-15

2.5 Vegetable processing in Sri Lanka

15

2.6 Domestic waste management

15-16 
CHAPTER 03

MATERIALS AND METHODS

$\begin{array}{ll}\text { 3.1 Method } & 17\end{array}$

$\begin{array}{ll}\text { 3.2 Primary data collection and selection of data } & 17\end{array}$

$\begin{array}{ll}3.3 \text { Pre-survey visit and interview } & 17\end{array}$

$\begin{array}{ll}\text { 3.4 Method of data collection } & 17\end{array}$

$\begin{array}{ll}3.5 \text { Period of the study } & 17\end{array}$

$\begin{array}{ll}3.6 \text { Recording and analysis of data } & 17\end{array}$

CHAPTER 04

RESULTS

4.1 The type of vegetable commonly get wasted $20-25$

4.2 Wastage of vegetables $26-31$

$\begin{array}{ll}4.3 \text { Correlations } & 32-41\end{array}$

4.4. Descriptive Statistics: \% total wastage 42

4.5 Correlation between the amounts purchased on the fourth week with amount purchased on other weeks $\quad 42-51$

4.6 Correlation between the total wastage on the fourth week with total wastage on other weeks

CHAPTER 05

DISCUSSION

CHAPTER 06

CONCLUSIONS

CHAPTER 07

RECOMMENDATIONS 
REFFERENCES

68-69

APPENDICES

8.1 Appendix 1

70-71

8.2 Appendix 2

73-152 


\section{LIST OF TABLES}

Pages

Table 1.1 : Amount of vegetable wastage at domestic level in UK

Table 2.1: The vegetable production and land usage in Sri Lanka

Table 2.2: Variation of prices of vegetables in 2007 and 2008

Table 2.3: All food items consumption and expenditure (average monthly per person) - Sri Lanka-2006/07

Table 2.4: Monthly per capita consumption of selected vegetables in different provinces of Sri Lanka

Table 2.5: Nutritive value of some vegetables. 


\section{LIST OF FIGURES}

Page

Fig 2.1: Structure of vegetable supply chain operating in Sri Lanka

Fig 4.1 The correlation between price of the vegetable $\&$ amount purchased

Fig 4.2 The correlation between Price of the vegetable \& amount wasted

Fig 4.3.1 The correlation between total amount wasted \& week of the month in Kurunegala district

Fig 4.3.2 The correlation between total amount wasted \& week of the month in Kandy district

Fig 4.4.1 The correlation between total amount wasted $\&$ income of the family (combined districts)

Fig 4.4.2 The correlation between total amount wasted \& income of the family in Kurunegala district

Fig 4.4.3. The correlation between total amount wasted $\&$ income of the family in Kandy district

Fig 5.5.1 The correlation between total amount wasted \& number of members of a family (combined districts)

Fig 5.5.2 The correlation between total amount wasted \& number of members of a family in Kurunegala district

Fig 5.5.3 The correlation between total amount wasted \& number of members of a family in Kandy district 


\section{ACKNOWLEDGEMENT}

I wish to express my sincere thanks and heartfelt gratitude to Prof. A.Bamunuarachchi and Dr. K.K.D.S.Ranaweera of Department of Food Science and Technology, University of Sri Jayawardanapura for consenting to be my supervisors and for the guidance, encouragement, advice and supervision given to me through out the study in spite of their busy schedule.

I also express my sincere gratitude the staff of the Department of Statistics, University of Sri Jayawardanapura for the assistance provided me in analyzing data.

Special thanks go to the participants of the survey for their time spent in completing the questionnaires, Mr. S. Rathnananda for the cooperation provided in collecting data and Ms. Manoja Senanayake of the Department of Statistics for the guidance provided in data analysis.

Finally I wish to thank my colleagues who helped me in numerous ways during time period of the research and the members of my family who were behind me all the time. 


\title{
A survey on extent of domestic waste of vegetables
}

\section{By}

\author{
R.H.I.D.Ranasinghe
}

\begin{abstract}
Vegetables constitute an important part of the human diet. Post harvest losses of fresh vegetables are considerably high in Sri Lanka. Nearly 270,000 metric tons of vegetables are being discarded as wastes. Out of the solid wastes collected from household, a large amount consists of processed and non-processed vegetables. When prices of vegetables are concerned, this makes a large amount of wastage of money. If the wastage can be minimized a large amount of money can be saved.
\end{abstract}

The survey on extent of domestic waste of vegetables was carried out in Kandy and Kurunegala districts with the intension of finding the percentage of total vegetable wastes, type of vegetables commonly get wasted, the factors behind wastage and to propose methods to minimize wastage.

The study was conducted in Kandy and Kurunegala districts using 30 houses from each district during a period of six weeks. Data was collected using questionnaires. First the vegetable wastes were sorted as processed and non-processed and then according to the type of vegetable. Processed and non-processed wastes of different types of vegetable were weighed and recorded. Data was analyzed using the statistical application 'Minitab'.

The total wastage of vegetables in Kandy district was $5.68 \%$ while $6.66 \%$ is recorded from Kurunegala. There was a correlation with the total wastage and the price of vegetable, monthly income and number of members in the family and week of the month. 
Mostly the vegetables get wasted at domestic level due to improper management at domestic level.

A further study can be carried out in other districts at different seasons, using this survey as a model. 


\section{CHAPTER 01}

\section{INTRODUCTION}

Food is required to maintain the life of animals and human beings. Food provides the major nutrients such as carbohydrates, proteins, fat, vitamins and minerals which are required to gain energy, for the growth and repair of the body respectively. Out of the different food types available fruits and vegetables play a major role providing the necessary nutrients.

Sri Lanka grows a wide variety of fruits and vegetables. Annually 72,342 hectares of land is consumed for the cultivation of vegetables while 161408 hectares are used for fruits. About $90 \%$ of the vegetables and fruits grown in Sri Lanka are being used for fresh consumption as processed products play a limited role in the domestic market (Ekanayake S., Ranawana C.K., 2003). Vegetables and fruits get wasted at different levels while coming from the farm to the market place. Part of the harvested vegetables get wasted at the farm yards while another portion get wasted during transportation from farm to the market place. This causes a large amount of wastage of money.

Finally vegetables and fruits get wasted at domestic levels. Vegetable wastage at domestic level is reported from all over Sri Lanka as well as from other countries too. Following shows how vegetables get wasted at domestic level in UK.

Table 1.1: Amount of vegetable wastage at domestic level in UK

\begin{tabular}{|l|l|l|l|l|}
\hline Fraction & $\begin{array}{l}\text { Multi- } \\
\text { storey } \\
\text { buildings }\end{array}$ & $\begin{array}{l}\text { Single- } \\
\text { family } \\
\text { homes }^{2)}\end{array}$ & $\begin{array}{l}\text { All } \\
\text { households } \\
\text { 3) }\end{array}$ & $\begin{array}{l}\text { Relative } \\
\text { distribution } \\
\text { (\%) }\end{array}$ \\
\hline $\begin{array}{l}\text { Non-processed vegetable } \\
\text { waste }\end{array}$ & 83,803 & 174,298 & 258,101 & 22.6 \\
\hline Other vegetable waste & 32,232 & 69,870 & 102,102 & 8.9 \\
\hline
\end{tabular}


Vegetable wastage at domestic level is reported from almost all areas in Sri Lanka. This causes wastage of large amount of money which is not aware by the people. Vegetables brought to house hold get wasted mostly due to the improper managing and handling at domestic level. The amount might get changed with the climate of the area, storage conditions and the type of market place. However the factors behind wastage and methods to minimize wastage are not identified exactly.

\subsection{Back ground to the study}

Kandy is a district of the central province while Kurunegala is a district of the "Jorth western province. Central province has a population of $2,567,000$ and 55.5 percapita daily energy intake from vegetables and North Western province has a population of 2,256,000 and 49.9 percapita daily energy intake from vegetables (Consumer finance \& socio-economic survey series of the central bank of Sri lanka 2003/2004). As the consumption of vegetable is at a considerable level Kandy and Kurunegala districts were selected for the study.

District- Kurunegala

No. of houses- 30

Areas- Kurunegala city limit

Redigama

Gokeralla

Polgahawela

Pothuhera

Ibbagamuwa

Wariyapola 
District- Kandy

No. of houses- 30

Areas- Kandy city limit

Peradeniya

Digana

Kundasale

Panideniya

Katugastota

Pilimathalawa

Houses of different economic levels, occupations and educational back grounds are found in these areas. And also these districts have a climate which is different from one another. Data on extent vegetable wastage at domestic level is not reported from these two districts. By considering the above reasons, households from different areas of Kandy and Kurunegala districts were selected for the study.

\subsection{Objectives of the study:}

- To gain information from people on how they currently manage the storage of fresh vegetables in the home and on the types of products that are commonly get wasted.

- To identify the factors behind vegetable wastage at domestic level

- To find the \% vegetable wastage and its relationship with 
- To identify the ways in which wastage of food can be reduced. 